\title{
Social economy companies in the times of crises: Entrepreneurship and survival
}

\author{
Núria Masferrer Llabinés (D), Patrícia Crespo(iD), Marian Buil-Fabregà(D) \\ Escola Superior de Ciències Socials i de l'Empresa de Tecnocampus, Universitat Pompen \\ Fabra - Càtedra d'Economia Social (Spain) \\ nmasferrer@tecnocampus.cat,pcrespo@tecnocampus.cat,mbuil@tecnocampus.cat
}

Received July, 2017

Accepted October, 2017

\section{Abstract}

Purpose: The work presented in this article is a study of the strategies carried out by social economy companies in times of crisis. This article analyses the financial characteristics of the cooperative companies created in Barcelona during the crisis period 2008-2013. This study aims to compare the financial characteristics of the cooperative companies analysed with the measures carried out to maintain their profitability in times of crisis.

Design/methodology: Statistical-descriptive analysis of the means and variations of the main financial indicators that are related to the measures taken by the companies of Social Economy in times of crisis. The data used have been provided by the Generalitat de Catalunya - Departament d'Empresa i Ocupació Direcció General d'Economia Social i Cooperativa i Treball Autònom for the reference period 2008-2013.

Findings: The cooperative companies created in Barcelona in the period of crisis 2008-2013 have the following features: their debt remains stable with a significant improvement in quality, and they display increases in long-term debt relative to short-term debt. Regarding collection and payment periods, there is an upward trend, but a reduction is confirmed in the last year of the sample. In that year, 2013, there is a trend change in the evolution of most of the analysed economic indicators. This change coincides with improvement in the conjuncture of the capital market and the economic environment in general.

Originality/value: To determine the economic and financial characteristics of the cooperative companies created in the period of crisis 2008-2013 with the aim of guiding the social entrepreneurs of the future.

Keywords: Entrepreneurship, Cooperatives, Social Economy, Crisis, Barcelona, Indebtedness, Liquidity, Profitability, Collection period, Payment period

Jel Codes: M13, M49

\section{Introduction}

After the financial crisis of 2008-2009, which is considered the most severe since the 1930s (FMI, 2010; Bagliano, Nobili \& Picillo, 2011; Ireland, 2011), the business environment is increasingly characterized by unexpected and unpredictable changes to which companies must respond quickly. This comes together with an increasing relevance of clients, who value those companies that report greater value to society (Carroll \& Buchholtz, 2012; Alonso-Almeida, Rocafort \& Borrajo, 2016). In response to this new paradigm, companies must include sustainable criteria in their strategies to respond to the values that customers demand (Kleiner, 
2013; Lubbers, 2016), while also taking internal measures to maintain their profitability and ensure their survival (Smallbone, Deakins, Battisti \& Kitching, 2012; Buil \& Rocafort, 2015).

Social economy companies seem to respond to the social values demanded by customers and society in general; these demands provide the fundamental principles that regulate these companies and generate changes in the way that entrepreneurs think and act, arising in response to the economic crisis (Fernández \& Ramón, 2013).

The territories that are considered leaders in cooperative enterprises are the Basque Country and Catalonia in first and second place, respectively, employing 54,337 and 41,323 people (Fernández, Miró \& Acedo, 2016). This accounts for $19.5 \%$ and $14.8 \%$ respectively, of the total number of people in Spain employed in cooperative enterprises (CEPES, 2016).

In terms of entrepreneurial environments, Barcelona is considered to have an entrepreneurial focus on the environment, infrastructure, and institutions and entrepreneurial culture that give impetus to new business initiatives. Furthermore, Barcelona has been recognized as an Entrepreneurship Hub, the 1st Smart City in the world, the 3rd city in the world in terms of the number of international conferences, the 4th best city in Europe for investment in start-ups, home to a total of 39 venture capital funds, the world capital of mobile and the European capital of innovation in the past few years. In addition, it has many congresses, events, programmes and awards for entrepreneurs such as the Biz Barcelona and some others with a great international reputation, such as the Mobile World Congress (Sorrell, 2015). Barcelona is also consolidating itself as a leading city in the promotion of the Social and Solidarity Economy, together with other cities of the world such as Paris, Seoul or Montreal (Barcelona Activa, 2016)

In light of Barcelona having an entrepreneurial focus (which occurred because the crisis occurred in the period analysed and because companies take measures to maintain their profitability and ensure their survival), the objective of this work is to observe the situation described by Smallbone et al. (2012) for companies in New Zealand and the UK, to determine if social economy companies in Barcelona created during the crisis follow the management pattern proposed by the authors.

To achieve this goal, the present article is structured in the following way: first, an introduction; second, a review of the literature on the strategies followed by social economy enterprises to survive in times of crisis; third, the characteristics of the sample selected, the variables analysed and the methodology used; fourth, the results of the analysis; fifth, the limitations derived therefrom; and, finally, the conclusions of the article.

\section{Literature review}

Periods of recession generate contradictory tendencies in the strategic decision making of companies; at the same time, these periods have an impact on business operations, affecting key variables such as sales, pricing policy or investment and financing decisions. Taking the right measures and adapting to the environment will condition the businesses' survival (Smallbone et al., 2012; Bamiatzi \& Kirchmaier, 2014; Cowling et al., 2014; Martin \& Sunley, 2014; Williams \& Vorley, 2014) and will contribute to entrepreneurship (Wright \& Stigliani, 2013; Davidsson \& Gordon, 2015).

According to Melián and Campos (2009, pp. 43-67), "The foundations of the Social Economy and workers' participation in companies are created by entrepreneurs. In the current situation of recession and financial crisis, Social Economy companies have proven to be a strategic option for local development of the socio-labour insertion, and they have an important role to develop as creative entities of employment in their localities, in addition to generating wealth, increasing the business fabric with quality employment and acting with efficiency and effectiveness as elements of social and territorial cohesion since they do not relocate."

The Social Economy is understood as the set of private companies formally organized to satisfy the needs of its partners through the market, producing goods and services and securing financing, and the distributions of benefit and decision making are not linked directly with the capital contributed by each partner, with one vote corresponding to each partner. (Stuart Mill \& Walras, 1970; Chaves \& Monzón, 2012). The types of companies considered social economy are cooperatives, mutual societies and associations (Gómez \& Savedra, 2012). All of these companies integrate the needs of the environment, offering solidarity and redistribution through internal 
forms of management like capitalist companies or traditional associations with the third sector (Peréz, Etxezarreta \& Guridi, 2008).

In this article, we first want to detect what the financial characteristics of the cooperatives created in Barcelona during the crisis are. The measures proposed by Smallbone et al. (2012), aimed at ensuring the survival of enterprises, affect different factors. The authors propose eight measures and several factors each, which are indicated in Table 1. In the first place, the measures taken in marketing and sales are focused on increasing sales, reducing sales prices or choosing to increase or reduce expenses in promotion and publicity. Second, the measures taken in the markets are summarized as selling to new customers, selling more to existing customers and selling in new markets. Third, measures taken on products and services focus on introducing new or improved products or services, reducing the range of products and services offered, and increasing the use of intellectual property. Fourth, measures taken in finance refer to renegotiations of supply costs, increases in held funds, reductions in customer collection times or increases in the repayment term to creditors, and increased debt financing. Fifth, measures taken to change the behaviour of the entrepreneur may be to work longer hours, cancel personal holidays, or sell personal assets to compensate for losses. Sixth, measures relating to production processes are summarized as working with new suppliers and investing in new equipment. In addition, finally, there are also measures taken in business organization such as changes in management functions and teams of management.

Not all the measures proposed by Smallbone et al. (2012) in Table 1 can be financially controlled. However, as the case to be analysed is about the cooperative companies created in Barcelona in times of crisis, the article focuses on the measures proposed by Smallbone that are observable and measurable via financial statements. These measures and their indicators are proposed in Table 2. For each measure, an indicator is defined that allows analysis of the evolution of the chosen variable. The only measures that will be analysed will be the ones carried out in finances grouped according to Amat (2003).

The economic and financial analysis of companies is widely used within the area of accounting and management in terms of calculating indicators and ratios from their accounting information at a theoretical and practical level. There are many references that use ratios for the economic and financial analysis of companies. (Amat, 2003; Álvarez, 1985; Banegas, Sánchez-Mayoral \& Nevado Peña, 1998; Bernstein, 1995; Castelló \& Lizcano, 1998; Foster, 1986; Rees, 1990; Rivero, 1996; Romero, 1996; Amat, Perramon \& Crespo, 2006; Crespo, Amat \& Mercader, 2013).

From this analysis, the results obtained from the actions and strategies executed by the companies during the crisis will help start-ups or cooperative companies to correctly define the resources, capacities, products, services, and types of clients necessary for the success of their business (Thomas, Clark \& Gioia, 1993) (Clark \& Mueller, 1996) (Smallbone et al., 2012). In short, this analysis will focus on the variables that increase or decrease the intention to undertake improvement measures and that increase the probability of survival of the newly created cooperative enterprises.

Based on what was stated in the previous section, the following research questions are formulated:

- Have cooperative enterprises established in Barcelona during the period of economic and financial crisis employed some of the actions and strategies proposed by Smallbone et al. (2012) at the financial level?

- What are the financial characteristics of cooperative enterprises created in Barcelona during the period of economic and financial crisis? How do they behave towards capitalist enterprises? 


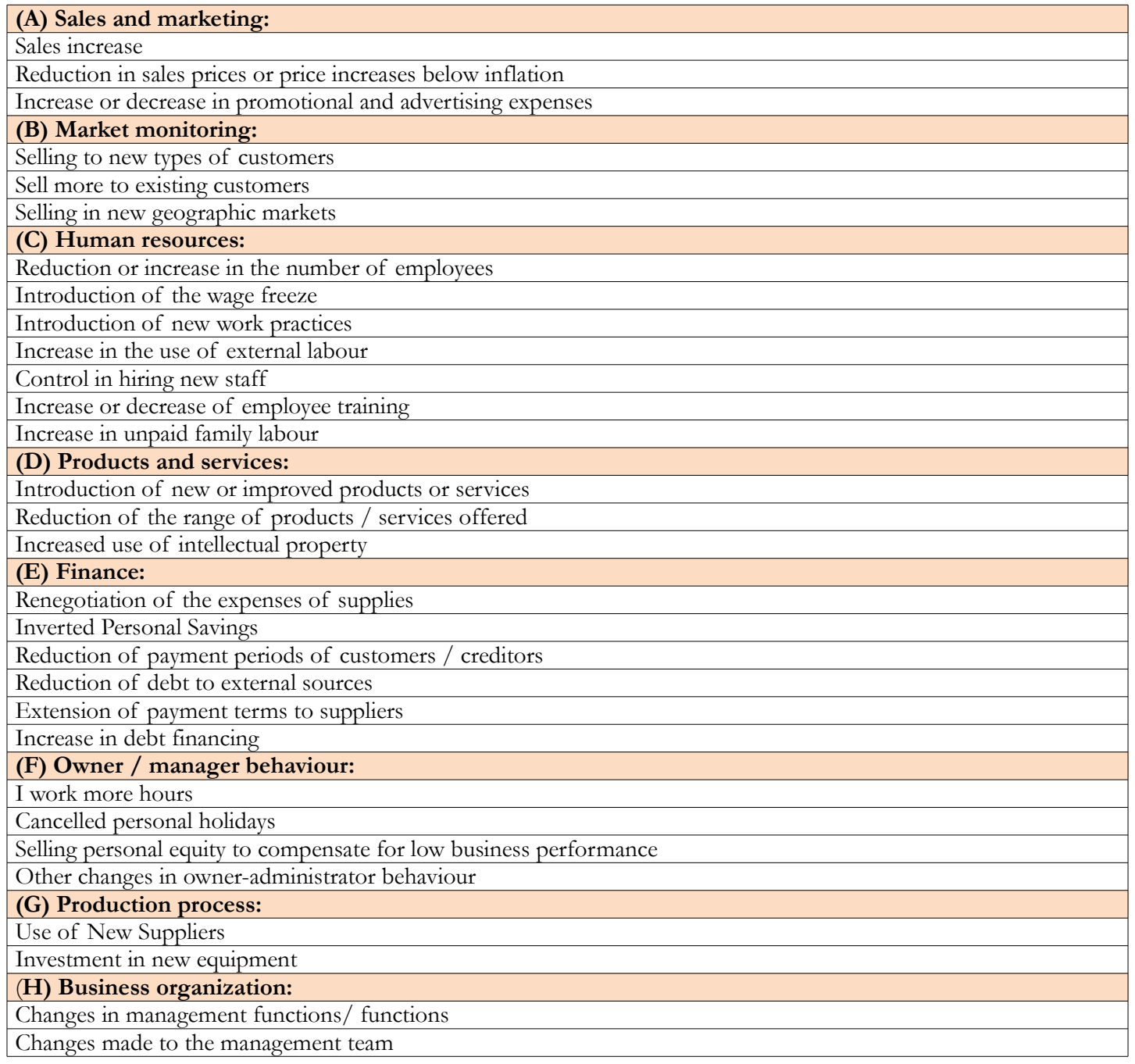

Table 1. Measures taken by companies to maintain or increase their profitability since early 2008 (Smallbone et al., 2012)

\section{(E) Finance:}

\section{Liquidity Ratios}

Indicator E1: Liquidity

Indicator E2: Manoeuvre Fund

Indicator E3: Working Capital on Current Liabilities

\section{Debt Ratios}

Indicator E4: Indebtedness

Indicator E5: Autonomy

Indicator E6: debt quality

Indicator E7: Cost of debt

Indicator E8: Payment Period

\section{Rotation Ratios}

Indicator E9: Non-current Asset Rotation

Indicator E10: Current Asset Rotation

Collection and Payment Management Ratios

Indicator E11: Collection Period

Indicator E12: Payment Period

Indicator E13: Difference

Profitability Ratios

Indicator E14: Financial Performance

Indicator E15: Economic Performance

Table 2. Measures and indicators taken by cooperative societies created and surviving in Barcelona 2008-2013 


\section{Design and methodology}

\subsection{Sample}

The data used have been provided by the Generalitat of Catalunya - Departament d'Empresa $i$ Ocupació - General Directorate of Social Economy and Cooperativa and Autonomous Work. The data consist of 182 cooperative societies, of which 49 had not made deposits to their annual accounts within the period 2008-2013. They have provided us the Balance Sheets and the Profit and Loss Accounts of these cooperative societies for the period, and the database has been prepared and tabulated.

The sample selection criteria used are as follows:

- Cooperative companies created in the period 2008-2013 with domicile in fiscal Barcelona.

- Period 2008-2013. 2008 was selected as the first year of the set as it coincides with the beginning of the economic crisis (IMF, 2010). The year 2013 is the last financial year for which data are available.

Table 3 shows a summary of the companies of the sample classified by secondary and tertiary sector, rejecting those that have not facilitated the sectors to which they belong.

\begin{tabular}{|l|r|r|}
\hline SECTOR & NUMBER OF COMPANIES & PERCENTAGE OF TOTAL \\
\hline Secondary & 11 & $9.16 \%$ \\
\hline Tertiary & 109 & $90.83 \%$ \\
\hline TOTAL & $\mathbf{1 2 0}$ & $\mathbf{1 0 0 \%}$ \\
\hline
\end{tabular}

Table 3. Characteristics of the sample

\subsection{Variables}

According to (Sabaté, Sabi, Saladrigues (2000) and Gómez and Miranda (2006), cooperative companies present a financing scheme related to the principles that govern them. Table 4 details this structure.

\begin{tabular}{|c|c|}
\hline \multicolumn{1}{|c|}{ EQUITY } & \multicolumn{1}{c|}{ LIABILITIES } \\
\hline -Social Capital & - For the partners \\
Compulsory contributions & Return accumulation fund \\
Voluntary contributions & Returns pending application \\
& Contributions not incorporated to the \\
-Reserve funds & capital and loans received from partners \\
Mandatory reserve funds & \\
Voluntary reserve funds & -For third parties \\
& Creditors \\
- Education and promotion fund & Public administrations \\
- Action of contributions & Provisions for risks and expenses \\
- Capital subsidies & Participatory titles \\
\hline
\end{tabular}

Table 4. Financial structure of the Cooperatives. (Sabaté, Sabi \& Saladrigues, 2000)

Considering this structure, the chosen variables will allow us to observe and measure, through financial statements, the measures taken by the companies created in Barcelona during the crisis period.

The ratios and indicators analysed have been grouped by their nature and are as follows:

- Liquidity ratios: The liquidity ratio is considered to be the quotient between current assets and current liabilities, and the Manoeuvre Fund is also proposed. Liquidity has been considered for each of the years of the reference period 2008-2013.

- Indebtedness ratios: The indebtedness ratio is considered to be the percentage of the companies' debt over total liabilities, the autonomy ratio, the quality of the debt and the cost of the debt, considering only the debt with cost. The percentage of indebtedness has been considered for each of the years of the reference period 2008-2013. 
- Collection and payment management ratios: the number of days for each of the years in the reference period 2008-2013 has been considered.

- Turnover Ratios: This ratio consists of the percentage of turnover of current and non-current assets for each of the years in the reference period 2008-2013.

- Profitability ratios: This ratio consists of the percentage of economic and financial profitability for each of the years of the reference period 2008-2013.

\subsection{Methodology}

A statistical-descriptive analysis of the means and variations of the variables proposed in the previous section is carried out. The objective of this analysis is to determine the financial characteristics of the cooperative companies that were created and that have survived in Barcelona during the period of economic and financial crisis and to see if they follow the measures proposed by Smallbone et al. (2012).

For this purpose, a balance sheet and income statement for the years studied are elaborated, and based on the data obtained, the economic and financial analysis is carried out with emphasis on the variables proposed. There is also a vertical analysis of the balance sheets for the different years.

\section{Implications and results}

\subsection{Vertical analysis}

The vertical analysis of the balance sheet consists of a calculation of the percentage that represents each equity group in relation to total assets, Amat (2003). The first conclusions can be obtained from the calculated percentages, from the following general guiding principles:

First, the current assets must be higher than, and if possible almost double, the current liability. This is necessary so that the company does not have liquidity problems and can attend to its payments. As seen in Table 5, in all the years analysed, current assets exceed current liabilities, but this does not reach double, so we can talk about serious liquidity problems.

Second, the realizable plus the disposable must be approximately equal to the current liabilities. This principle qualifies the former as it is possible that a company has very high current assets in the form of stocks and therefore does not have cash to make payments. The data from the sample confirm that the percentage of stocks over total current assets is very low (between $1 \%$ and $10 \%$ ) in the period under review, so the first principle is reaffirmed, and we cannot speak of serious problems of liquidity.

Finally, a company's own capital must amount to $40 \%$ or $50 \%$ of total liabilities. This percentage of equity is necessary so that the company is sufficiently capitalized and its indebtedness is not excessive. Analysing the data in Table 5, the value of net worth goes from $19 \%$ in 2008 to $11 \%$ in 2013 . Caution must be exercised; the cooperative enterprises in the sample are de-capitalized and therefore over-indebted due to lack of funds and debts. Decapitalization may be due to the existence of continued losses that is a habitual situation in the newly created companies.

We should go deeper into the economic and financial analysis of newly created cooperative enterprises in the period under review to draw firmer conclusions. Below, an analysis of the main ratios has been performed. 


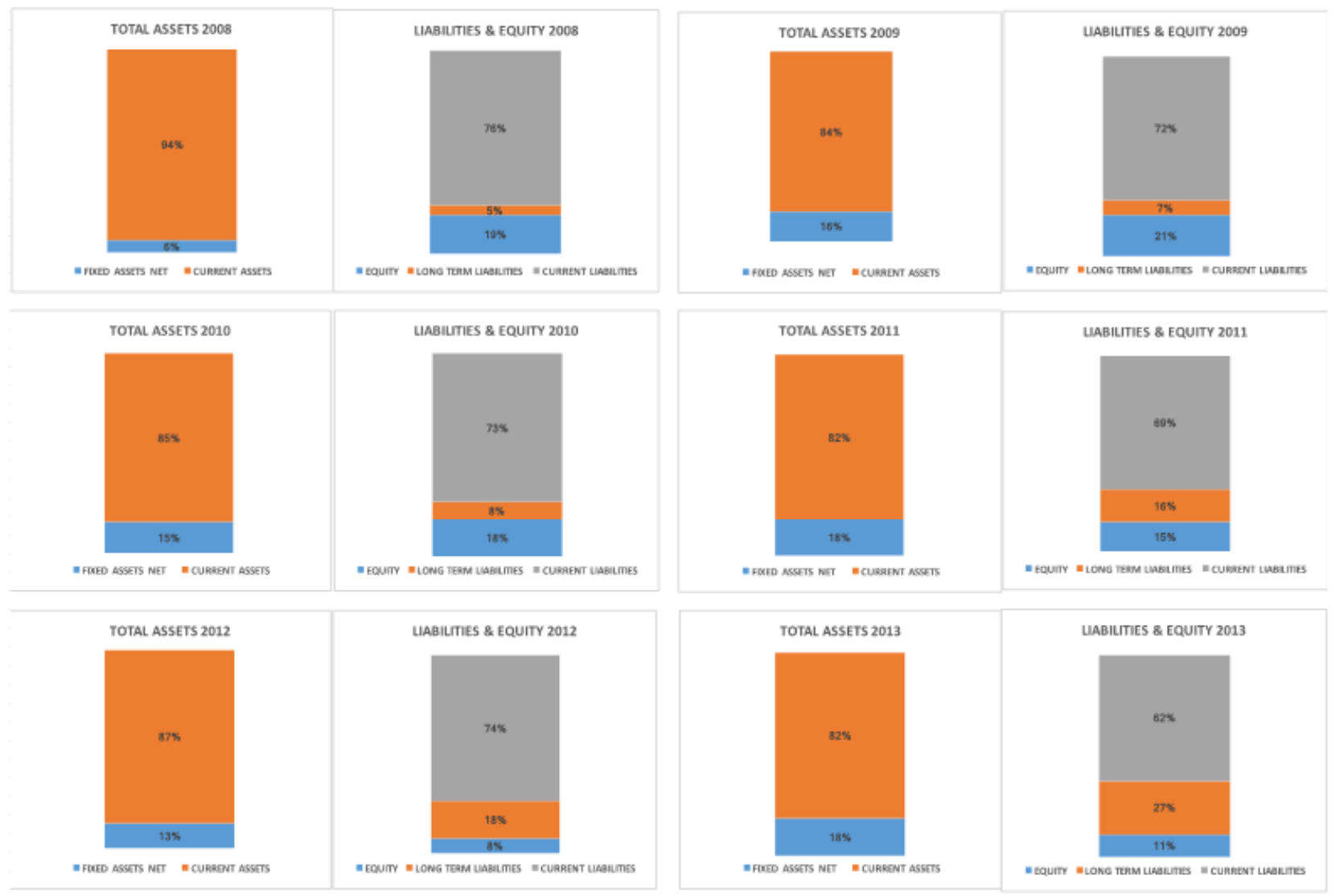

Table 5. Vertical Analysis of the Balance Sheet, 2008-2013

\subsection{Ratio Analysis}

\subsubsection{Liquidity Ratios}

According to the data provided in Table 6, although the liquidity ratio is below the recommended reference value, which ranges from 1.5 to 2 , its evolution is favourable and very close to 1.5.

This ratio is directly related to the Manoeuvre Fund, FM. This allows us to know the patrimonial structure of the cooperative companies. Having a sufficient FM is a guarantee for the stability of cooperative enterprises, since from the point of view of financing, it is the part of the company's current assets that is financed with the company's own resources.

The Working Capital Fund must be positive; otherwise, non-current assets would be financed with current liabilities and would generate financial problems. According to the data, it is observed that the Working Capital Fund is positive across all the analysed years. This assertion is reinforced by the working capital ratio of current liabilities, whose reference value ranges from 0.8 to 1 . As already noted in the vertical analysis, we cannot speak of serious liquidity problems.

If we analyse the variation in percentage of the evolution of the liquidity ratio for the cooperative companies of the sample, there is generally a slightly downward trend, except for in the last year, where there is a rebound. The ratio of working capital to current liabilities decreases throughout the analysed period, with values between - $3 \%$ and $-8 \%$. 


\begin{tabular}{|l|r|r|r|r|r|r|}
\hline Liquidity ratios & \multicolumn{1}{|c|}{$\mathbf{2 0 0 8}$} & \multicolumn{1}{|c|}{$\mathbf{2 0 0 9}$} & \multicolumn{1}{c|}{$\mathbf{2 0 1 0}$} & \multicolumn{1}{c|}{$\mathbf{2 0 1 1}$} & \multicolumn{1}{c|}{$\mathbf{2 0 1 2}$} & \multicolumn{1}{c|}{2013} \\
\hline Liquidity & 1.22 & 1.17 & 1.15 & 1.20 & 1.18 & 1.31 \\
\hline Variation in \% & & $-4.2 \%$ & $-1.7 \%$ & $4.2 \%$ & $-1.8 \%$ & $10 .-\%$ \\
\hline FM on PC & 1.16 & 1.07 & 1.04 & 0.96 & 0.93 & 0.88 \\
\hline Variation in \% & & $! 8.02 \%$ & $! 2.96 \%$ & $! 7.33 \%$ & $! 3.32 \%$ & $! 5.10 \%$ \\
\hline Variation in \% & & $41 \%$ & $48 \%$ & $24 \%$ & $34 \%$ & $-45 \%$ \\
\hline
\end{tabular}

Table 6. Ratio of Liquidity Data

\subsubsection{Debt ratios}

If the total percentage of debt is analysed in relation to total liabilities, considering that the reference value is between $40 \%$ and $60 \%$, it is observed that newly created cooperatives in the crisis period 2008- 2013 have a very high percentage, as shown in Table 7 . The autonomy ratio, as it is complementary to that of debt, has very low values, which makes relevant the low financial autonomy of the cooperative companies, since they are of New Creation.

The variation of debt is positive throughout the period except for the last year. Autonomy grows in 2013.

\begin{tabular}{|l|r|r|r|r|r|r|}
\hline Indebtedness ratios & $\mathbf{2 0 0 8}$ & \multicolumn{1}{|c|}{$\mathbf{2 0 0 9}$} & \multicolumn{1}{|c|}{$\mathbf{2 0 1 0}$} & \multicolumn{1}{|c|}{$\mathbf{2 0 1 1}$} & \multicolumn{1}{c|}{$\mathbf{2 0 1 2}$} & \multicolumn{1}{c|}{$\mathbf{2 0 1 3}$} \\
\hline Indebtedness & $81 \%$ & $79 \%$ & $82 \%$ & $85 \%$ & $92 \%$ & $89 \%$ \\
\hline Variation Indebtedness in \% & & $-2.01 \%$ & $2,95 \%$ & $387 \%$ & $8.47 \%$ & $-3.51 \%$ \\
\hline Autonomy & 0.23 & 0.26 & 0.22 & 0.18 & 0.08 & 0.12 \\
\hline Variation Autonomy in \% & & $10.88 \%$ & $-13.94 \%$ & $-20.48 \%$ & $-51.96 \%$ & $46.49 \%$ \\
\hline Quality on the debt & $82 \%$ & $61 \%$ & $65 \%$ & $43 \%$ & $47 \%$ & $43 \%$ \\
\hline Variation Quality on the debt in \% & & $-25.60 \%$ & $7.46 \%$ & $-34.10 \%$ & $10.23 \%$ & $-9.45 \%$ \\
\hline Cost of the debt & $0.64 \%$ & $0.85 \%$ & $1.82 \%$ & $2.22 \%$ & $1.72 \%$ & $1.44 \%$ \\
\hline Variation Cost of the debt in \% & & $32.31 \%$ & $113.28 \%$ & $21.97 \%$ & $-22.28 \%$ & $-16.00 \%$ \\
\hline
\end{tabular}

Table 7. Data Ratios of Indebtedness

According to Buil and Rocafort (2015), capitalist enterprises newly created in the period 2008-2013 have high indebtedness, with a ratio that remains at approximately $75 \%$. In the case of cooperative enterprises this value is also high, approximately $85 \%$.

Regarding the debt quality ratio, the lower the value, the better quality it presents. The data show a very high value for the year 2008, which is reduced to half in 2013. The improvement of the quality of the debt is shown.

Analysing the last ratio in Table 7, the lower the value of the cost of debt, the cheaper the remunerated debt held by the company will be, therefore reflecting a more favourable situation. During the years 2009-10 and 2011 due to the difficulty of accessing to the capital market due to the crisis, this ratio has increased, but from 2012 on, this ratio is decreasing under the best market conditions.

If we observe changes in debt quality ratios and the cost of debt, in the first case, the variation is changing over the analysed period, although it tends to be reduced by reference to the first and last year of the sample. The cost of debt has grown from the year 2012.

\subsubsection{Rotation ratios and payment and payment management ratios}

The ratios of rotation presented in Table 8 allow us to study the performance that is obtained from assets. Higher values will mean that more sales are generated with the asset, indicating a better use of it.

The data show a drastic reduction with respect to non-current assets, while practically, it remains in the current assets. This means that newly created cooperatives will need a larger investment.

In general, the variations of the rotation ratios are negative, observing an improvement in the last year of the sample. 


\begin{tabular}{|l|r|r|r|r|r|r|}
\hline Rotation ratios & \multicolumn{1}{c|}{$\mathbf{2 0 0 8}$} & \multicolumn{1}{c|}{$\mathbf{2 0 0 9}$} & \multicolumn{1}{c|}{$\mathbf{2 0 1 0}$} & \multicolumn{1}{c|}{$\mathbf{2 0 1 1}$} & \multicolumn{1}{c|}{$\mathbf{2 0 1 2}$} & \multicolumn{1}{c|}{$\mathbf{2 0 1 3}$} \\
\hline ANC Rotation & 57.46 & 15.88 & 15.40 & 11.72 & 11.55 & 11.39 \\
\hline Variation ANC Rotation in \% & & $-72 \%$ & $-3 \%$ & $-24 \%$ & $-1 \%$ & $-1 \%$ \\
\hline Rotation AC & 3.99 & 2.93 & 2.81 & 2.52 & 1.73 & 2.57 \\
\hline Variation Rotation AC in \% & & $-27 \%$ & $-4 \%$ & $-11 \%$ & $-31 \%$ & $49 \%$ \\
\hline $\begin{array}{l}\text { Payment Management and } \\
\text { Payment Rates }\end{array}$ & $\mathbf{2 0 0 8}$ & $\mathbf{2 0 0 9}$ & $\mathbf{2 0 1 0}$ & $\mathbf{2 0 1 1}$ & $\mathbf{2 0 1 2}$ & $\mathbf{2 0 1 3}$ \\
\hline Collection Period & 61.1 & 93.3 & 64.9 & 98.9 & 153.5 & 81.9 \\
\hline Variation Collection Period in \% & & 0.5 & -0.3 & 0.5 & 0.6 & -0.5 \\
\hline Payment Period & 62.5 & 160.1 & 174.7 & 194.0 & 286.0 & 158.5 \\
\hline Variation Period of Payment in \% & & 1.6 & 0.1 & 0.1 & 0.5 & -0.4 \\
\hline Difference & -1.4 & -66.7 & -109.8 & -95.1 & -132.5 & -76.7 \\
\hline
\end{tabular}

Table 8. Rotation Ratio data and collection and payment management

Collection and payment management ratios serve to check the evolution of the policy of collections and payments to customers and suppliers. It is interesting that the collection period is longer than the payment period, since clients would finance payment to suppliers, and companies do not need extra resources to finance them.

Analysing the difference between the collection period and the payment period of the data in Table 8, it is observed that the difference is negative, which means that the company pays its suppliers before it charges its customers. This difference is high, but it should be noted that in periods of crisis, companies have problems with recovery.

If variations are observed, the collection period increases, as does the payment period, except for in the last year, when both are reduced.

\subsubsection{Profitability ratios}

Regarding profitability ratios, the higher these ratios are, the better. Referring to economic profitability, a higher value indicates that more productivity of the asset is obtained. Financial profitability is the most important ratio for companies with lucrative character. Financial profitability measures the net profit generated in relation to the investment of the owners of the company; it must be positive.

\begin{tabular}{|l|c|r|r|r|r|r|}
\hline Profitability ratios & \multicolumn{1}{|c|}{$\mathbf{2 0 0 8}$} & \multicolumn{1}{c|}{$\mathbf{2 0 0 9}$} & \multicolumn{1}{c|}{$\mathbf{2 0 1 0}$} & \multicolumn{1}{c|}{$\mathbf{2 0 1 1}$} & \multicolumn{1}{c|}{$\mathbf{2 0 1 2}$} & \multicolumn{1}{c|}{$\mathbf{2 0 1 3}$} \\
\hline Financial profit & $-18.3 \%$ & $-23.2 \%$ & $-22.3 \%$ & $-3.3 \%$ & $-2.7 \%$ & $-14.7 \%$ \\
\hline in \% & & $! 27.10 \%$ & $3.8 \%$ & $85.33 \%$ & $17.61 \%$ & $! 446.28 \%$ \\
\hline Economic profitability & $-3.9 \%$ & $-4.7 \%$ & $-3.8 \%$ & $-0.2 \%$ & $0.01 \%$ & $-0.9 \%$ \\
\hline in \% & & $20.01 \%$ & $! 19.32 \%$ & $! 93.98 \%$ & $! 106.36 \%$ & $! 6377.56 \%$ \\
\hline
\end{tabular}

Table 9. Data Profitability Ratios

In Table 9, the data show negative values for all years because after interest and taxes, net profits are negative.

If we observe the variations and compare the first year of the sample with the last, the evolution is favourable in the sense that the ratios are less negative.

According to Buil and Rocafort (2015), capitalist enterprises newly created in the period 2008-2013 maintain financial profitability levels close to $42 \%$ in the first two years of the company's life. Profitability levels decrease at a rate of 10 points in the following 3 years and showing a slight rebound in the last, 2013. Buil and Rocafort argue that profitability is not derived from profit but from the typology of indebtedness. Comparing this conclusion with the results presented, we can see that this effect does not occur in the case of cooperative enterprises.

\section{Limitations}

The selected sample only reflects the measurements and factors proposed by Smallbone et al. (2012) that can be controlled financially. The data used, provided by the Generalitat de Catalunya - Departament d'Empresa i Ocupació - 
Directorate General d'Economia Social i Cooperativa i Treball Autònom, are financial statements (balance sheets and income accounts).

These are quantitative variables that can measure the economic and financial situation of cooperative enterprises without collecting qualitative variables. Some aspects should be appreciated, such as the personality of the social entrepreneur, their level of knowledge, the degree of motivation of the cooperative/employee partners or the environment in which they operate. These aspects are foundational for understanding what variables depend on the success and survival of newly created cooperative enterprises. Qualitative variables that allow the analysis to be completed from the information in the annual accounts will be the object of future research.

Another limitation that we encountered is that we do not have data for the number of employees in each company. This has prevented us from doing a study of the human resource variable proposed by Smallbone et al. (2012), of special relevance in social economy enterprises (Rodrigo, 1995; Díaz \& Marcuello, 2010).

\section{Added value}

This paper produces several conclusions that will make it possible to determine the economic and financial characteristics of the cooperative companies created in the period of crisis 2008-2013 with the aim of guiding the social entrepreneurs of the future.

The hypotheses presented in this study will be subject to further analysis in which the quantitative information will be compared with the results of interviews with the cooperative partners/employees of the companies that are the subject of our analysis.

The conclusions of this work are the result of a study of the evolution of the analysed variables that allow us to know the economic and financial characteristics of the cooperative companies created in Barcelona in times of crisis and to state whether they follow the measures proposed by Smallbone et al. (2012).

The first conclusion drawn from the analysis is that in the last year of the sample, 2013, there is a trend change in the evolution of most economic indicators analysed. This change corresponds with a situation of improvement in the conjuncture of the capital market and the economic environment in general.

The second conclusion shows that cooperative enterprises created in the period 2008-2013 follow the financial measures proposed by Smallbone et al. (2012) with some nuances. Indebtedness remains stable, but a significant improvement in quality has to be highlighted; it increases long-term debt relative to short-term debt. Collection and payment deadlines, contrary to the measures proposed by Smallbone et al. (2012), followed an upward trend, but a reduction is confirmed in the last year of the sample.

Finally, there is a third conclusion. Newly created capitalist enterprises in the period 2008-2013, according to Buil and Rocafort (2015), have a high level of indebtedness, with a ratio that remains at approximately $75 \%$. In the case of cooperative enterprises this value is also high, approximately $85 \%$. In addition, newly created capitalist companies in the period 2008-2013 maintain financial profitability levels close to $42 \%$ in the first two years of the company's life, decreasing at a rate of 10 points in the following 3 years and showing a slight rebound in the last, 2013. They argue that profitability is not derived from profit but from the typology of indebtedness. Comparing this with the presented results, we can see that this effect does not occur in the case of cooperative enterprises.

Cooperative enterprises seem to adapt more slowly in response to periods of crisis.

\section{Declaration of Conflicting Interests}

The authors declared no potential conflicts of interest with respect to the research, authorship, and/or publication of this article.

\section{Funding}

The authors received no financial support for the research, authorship, and/or publication of this article. 


\section{References}

Álvarez, J. (1985). Análisis de Balances. San Sebastián: Editorial Donostiarra.

Alonso-Almeida, M., Rocafort, A., \& Borrajo, F. (2016). Shedding Light on Eco-Innovation in Tourism: A Critical Analysis. Sustainability, 8(2), 1262. https://doi.org/10.3390/su8121262

Amat, O. (2003). Anàlisi d'Estats Financers. Fonaments i aplicacions. Barcelona: Gestió 2000.

Amat, O., Perramon, J., \& Crespo, P. (2006). Anälisi d'estats financers de la indústria catalane 2004: Comptes anuals de 59 sectors, 26 ràtios per a cada sector. Generalitat de Catalunya. Departament d'Innovació, Universitats i Empresa.

Bagliano, F.C., Nobili, A., \& Picillo, C. (2011) The great recession: US dynamics and spillovers to the world economy. Journal of Banking and Finance, 36(1), 1-13. https://doi.org/10.1016/j.jbankfin.2011.06.002

Bamiatzi, V.C., \& Kirchmaier, T. (2014). Strategies for superior performance under adverse conditions: A focus on small and medium-sized high-growth firms. International Small Business Journal, 32(3), 259-284. https://doi.org/10.1177/0266242612459534

Banegas, R., Sánchez-Mayoral, R., \& Nevado Peña, D. (1998). Análisis por ratios de los Estados Contables Financieros (Análisis externo). Madrid: Civitas.

Barcelona Activa (2016). Available at: www.barcelonactiva.cat (Last access date: April, 2017).

Bernstein, L. (1995). Análisis de Estados Financieros. Bilbao: Deusto.

Buil, F.M., \& Rocafort, N.A. (2015). Emprendimiento y supervivencia empresarial en época de Crisis: El caso de Barcelona. Intangible Capital, 12(1), 95-120.

Carroll, A., \& Buchholtz, A. (2012). Business and Society Ethics, sustainability and Stakeholder Management (8th edition). Boston, Massachusetts: South-Western Cengage Learning.

Castelló Taliani, E., \& Lizcano Álvarez, J. (1998). La mejora de las entidades públicas en la Europa del Euro. Papel del sistema ABC/ABM. El Euro y la Contabilidad de Gestión en la Competitividad Empresarial, 11, 231-255.

CEPES (2016). Estadísticas de las Entidades de Economía Social. España

Chaves, R., \& Monzón, J. (2012). Beyong the crisis: The social economy, prop of a new model of sustainable development. Service Business, 6(1), 5-26. https://doi.org/10.1007/s11628-011-0125-7

Clark, P., \& Mueller, F. (1996). Organisations and nations: From universalism to institutionalism?. British Journal of Management, 7(2), 125-139. https://doi.org/10.1111/j.1467-8551.1996.tb00110.x

Cowling, M., Liu, W., Ledger, A. et al. (2014). What really happens to a small and medium-sized enterprises in a global economic recession? UK evidence on sales and job dynamics. International Small Business Journal. Epub ahead of print 13 January. https://doi.org/10.1177/0266242613512513

Crespo, P., Amat, N., \& Mercader R. (2013). La fiabilitat de la informació financera i el seu impacte per analistes i inversors. El cas de Pescanova. Revista de Comptabilitat i Direcció, ACCID, 16, 291-314.

Davidsson, P., \& Gordon, S.R. (2015). Much ado about nothing? The surprising persistence of nascent entrepreneurs through macroeconomic crisis. Entrepreneurship Theory and Practice, 40(4), 915-941. https://doi.org/10.1111/etap.12152

Díaz, M., \& Marcuello, C. (2010). Impacto económico de las cooperativas. La generación de empleo de las sociedades cooperativas y su relación con el PIB. CIRIEC-España, Revista de Economía Pública, Social y Cooperativa, 67, 23-24.

Fernández, M.A., Miró, I., \& Acedo, I. (2016). La economía social y solidaria en Barcelona (pp. 20). Barcelona: IMG MARGE.

Fernández, E., \& Ramón, R. (2013). El efecto de la crisis en dos sectores importantes de cooperativas valencianas con sus homólogas en las sociedades de capital. CIRIEC-España, Revista de Economía Pública, Social y Cooperativa, 79, 219-242.

Foster, G. (1986). Financial Statement Analysis. Englewood Cliffs: Prentice Hall. 
FMI (I.A.) (2010). Apoyar una recuperación mundial equilibrada.

Gómez, M., \& Savedra, E. (2012). Economia Social: Un ejemplo privilegiado de Organizaciones Socialmente Responsables. Madrid, España: Cointegra. Retrieved from: http://www.compromisorse.com/responsabilidad-social/servicios-aempresas/cointegra/

Gómez, P., \& Miranda, M. (2006). La caracterización financiera y contable del capital social a la luz de los principios cooperativos. REVESCO, Revista de Estudios Cooperativos, 90, 7-25.

Ireland, P.N. (2011). A new Keynesian perspective on the great recession. Journal of Money, Credit and Banking, 43(1), 31-54. https://doi.org/10.1111/j.1538-4616.2010.00364.x

Kleiner, A. (2013). The dynamic capabilities of David Teece. Strategy + Business, November 11, 2013. Retrieved from: https://www.strategy-business.com/article/00225

Lubbers, R.J. (2016). Selective decision making during opportunities for preventive maintenance. Eindhoven: Technische Univresiteit Eindhoven.

Martin, R., \& Sunley, P. (2014) On the notion of regional economic resilience: Conceptualization and explanation. Journal of Economic Geography. Oxford University Press, 15(1), 1-42.

Melián, N.A., \& Campos, C.V. (2009). Emprendedurismo y Economía Social como mecanismo de inserción laboral en tiempos de crisis. REVESCO, 100(Extraordinario 2010 Monográfico), 43-67.

Peréz, J.C., Etxezarreta, E., \& Guridi, L. (2008). ¿De qué hablamos cuando hablamos de Economía Social Solidaria? Concepto y nociones afines?. Bilbao: XI Jornadas de Economía Crítica.

Rees, B. (1990). Finacial Analysis. Hertfordshire: Prentice Hall.

Rivero, P. (1996). Análisis de balances y estados complementarios. Madrid: Alianza Universidad Textos.

Rodrigo, B. (1995). La excelencia empresarial en la sociedad cooperativa. CIRIEC-España, Revista de Economía Pública, Social y Cooperativa, 19, 43-53.

Romero, C. (1996). Introducción a la financiación empresarialy análisis bursátil. Madrid: Alianza Universidad Textos.

Sabaté, P., Sabi, X., \& Saladrigues, R. (2000). Cooperativas versus sociedades mercantiles. El sector frutero en Lleida. CIRIEC- España, Revista de Economía Pública, Socialy Cooperativa, 34, 51-70.

Smallbone, D., Deakins, D., Battisti, M., \& Kitching, J. (2012). Small business responses to major economic downturn: Empirical perspectives from New Zealand and the United Kingdom. International Small Business Journal, 0(0): 1-24. https://doi.org/10.1177/0266242612448077

Sorrell, S. (2015). Smart cities: Strategies, Energy, Emissions \& Cost Savings 2014-2019. Juniper Research. Retrieved from: www.juniperresearch.com/press/press-releases/barcelona-named-global-smart-city-2015 (Last access date: March, 2017).

Thomas, J., Clark, S., \& Gioia, D. (1993). Strategic sensemaking and organizational performance: Linkages among scanning, interpretation, action and outcomes. Academy of Management Journal, 36(2), 239-270. https://doi.org/10.2307/256522

Wright, M., \& Stigliani, I. (2013) Entrepreneurship and Growth. International Small Business Journal, 31, 3-22. https://doi.org/10.1177/0266242612467359

Williams, N., \& Vorley, T. (2014) Economic resilience and entrepreneurship: Lessons from the Sheffield City Region. Entrepreneurship \& Regional Development, 26(3-4), 257-281.

Intangible Capital, 2018 (www.intangiblecapital.org)

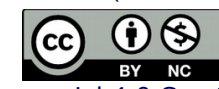

Article's contents are provided on an Attribution-Non Commercial 4.0 Creative commons International License. Readers are allowed to copy, distribute and communicate article's contents, provided the author's and Intangible Capital's names are included. It must not be used for commercial purposes. To see the complete license contents, please visit https://creativecommons.org/licenses/by-nc/4.0/. 